\title{
Phosphorus Balance and Soil Phosphorus Status in Paddy Rice Fields with Various Fertilizer Practices
}

\author{
Toshiyuki Nagumo, Shintaro Tajima, Sanae Chikushi and Ayako Yamashita \\ (Faculty of Agriculture, Shizuoka University, Ohya 836, Shizuoka 422-8529, Japan)
}

\begin{abstract}
Excess phosphorus (P) has accumulated in Japanese paddy soils, due to fertilizer $\mathbf{P}$ inputs over crop requirement for several decades, and improvement of the excess of $P$ is necessary in view of environmental conservation. This study aimed to evaluate the input/output balance of $\mathbf{P}$ related to soil $\mathbf{P}$ status in paddy rice systems, and to obtain a practical indication. Irrigated rice (Oryza sative L.) was cultivated on a gley soil from 1997 to 2006. Six field plots fertilized with commercial fertilizer, animal waste composts, green manure and none were included. Phosphorus input varied among plots from 0 to $73 \mathrm{~kg} \mathrm{ha}^{-1} \mathrm{yr}^{-1}$. Rice $\mathbf{P}$ uptake was approximately $20 \mathrm{~kg} \mathrm{ha}^{-1}$, indicating no response to the $P$ input. This was attributed to a large amount of plant-available Bray- and Truog-P in our soils. In our fields, paddy rice could be cultivated with no P-containing fertilizer or amendment. As a result, increase in the $\mathbf{P}$ input led to an increase in partial P balance (PPB). Cumulative increase in PPB resulted in the increase in soil total P, whereas cumulative decrease of PPB tended to decrease it. Excess accumulation of the soil $P$ results in a loss of $P$ into the environment. We concluded that $P$ fertilization should be restricted to $20 \mathrm{~kg} \mathrm{ha}^{-1} \mathrm{yr}^{-1}$ (corresponding to $46 \mathrm{~kg} \mathrm{ha}^{-1} \mathrm{yr}^{-1}$ as $\mathrm{P}_{2} \mathrm{O}_{5}$ ), based on evenly balanced $\mathrm{P}$ input with the rice $\mathbf{P}$ uptake. It is also important to include all of the $\mathbf{P}$-containing fertilizers and amendments when determining the amount of application.
\end{abstract}

Key words: Available soil phosphorus, Paddy soil, Partial phosphorus balance, Phosphorus recommendation, Soil phosphorus accumulation.

The major agricultural land use in Japan is the paddy rice field. Nowadays about $30 \%$ of phosphorus (P) fertilizer is consumed in the paddy rice field (Nishio, 2002; Mishima et al., 2003), while excess $\mathrm{P}$ accumulation in the paddy field has been stressed in Japan. Eighty percent of the paddy fields investigated nation-wide had a plantavailable Truog-P over the diagnostic standard in surface soil (44 $\mathrm{mg} \mathrm{kg}^{-1}$ as P) (Obara and Nakai, 2004). In cooltemperate Hokkaido, northern Japan, almost all the investigated paddy fields had more Bray-P than the standard (Goto et al., 2003). Increase in $\mathrm{P}$ accumulation enhances a potential loss of $\mathrm{P}$ through soil erosion and/or leaching in paddy rice field (e.g. Zhang et al., 2003; Shan et al., 2005; Kim et al., 2006; Ooya et al., 2007) as well as in the other agricultural land (Sharpley et al., 2001; Hart et al., 2004). Almost all of the $\mathrm{P}$ resource in Japan is imported, and the source may be depleted in the near future. The thrifty application of $\mathrm{P}$ fertilizer and effective use of excess $\mathrm{P}$ currently accumulated in soil, are important for conservation of the resource and environment.

Phosphorus balance could be determined by two major components: anthropogenic input as inorganic and organic fertilizers and amendments, and output of harvested crops including by-products like straw (Nanzyo, 1996; Cho et al., 2000; Pheav et al., 2005). In contrast, input of seeds and that through irrigation and atmospheric deposition, and outputs through surface drainage and leaching were considered to be usually low in one or more order of magnitude (Nanzyo, 1996; Cho et al., 2000; Pheav et al., 2005). Therefore, partial P balance (PPB), which is easily estimated by subtracting the $\mathrm{P}$ harvest from the input of $\mathrm{P}$ fertilizers and amendments, provides the information equivalent to entire $\mathrm{P}$ balance. The correlations between such PPB and increment in total P content (e.g. Blake et al., 2003; Lee et al., 2004; Han et al., 2005) or plantavailable P test value in soil (e.g. Dorbermann et al., 1996; Nishio, 2003; Han et al., 2005) have been reported. These results indicate that $\mathrm{PPB}$ is a useful tool for predicting the change in soil $\mathrm{P}$ status and recommending the amount of P application practically. Ono et al. (1999) investigated the $\mathrm{P}$ removal through the export of harvested rice grain across 26 sites and 18 varieties in Japan, and proposed a $\mathrm{P}$ input to sufficiently balance the $\mathrm{P}$ removal. Studies determining whether or not the uptake of $\mathrm{P}$ is independent 
Table 1. Fertilizer practice $\left(\mathrm{kg} \mathrm{ha}^{-1}\right.$ as $\left.\mathrm{P}\right)$ during 1997 to 2006.

\begin{tabular}{|c|c|c|c|c|c|c|c|c|c|c|c|c|}
\hline \multicolumn{2}{|c|}{ Field Plot } & \multirow{2}{*}{$\frac{1997}{47.1}$} & \multirow{2}{*}{$\frac{1998}{47.1}$} & \multirow{2}{*}{$\frac{1999}{47.1}$} & \multirow{2}{*}{$\frac{2000}{47.1}$} & \multirow{2}{*}{$\frac{2001}{47.1}$} & \multirow{2}{*}{$\frac{2002}{47.1}$} & \multirow{2}{*}{$\frac{2003}{20.9}$} & \multirow{2}{*}{$\frac{2004}{20.9}$} & \multirow{2}{*}{$\frac{2005}{20.9}$} & \multirow{2}{*}{$\frac{2006}{20.9}$} & \multirow[t]{2}{*}{ average } \\
\hline $\mathrm{T} 1$ & Basal fertilizer & & & & & & & & & & & \\
\hline & Top-dressing & 5.2 & 5.2 & 5.2 & 5.2 & 5.2 & 5.2 & 5.2 & 5.2 & 5.2 & 5.2 & \\
\hline & Silica amendments & & & 34.9 & 34.9 & & 34.9 & 34.9 & 34.9 & 34.9 & 34.9 & \\
\hline & Rice Straw & 4.1 & 3.4 & 3.7 & 4.0 & 4.6 & 3.7 & 3.2 & & & & \\
\hline & Net $\mathrm{P}$ input & 56.5 & 55.8 & 91.0 & 91.3 & 57.0 & 91.0 & 64.3 & 61.1 & 61.1 & 61.1 & 69.0 \\
\hline \multirow[t]{4}{*}{$\mathrm{T} 2$} & $\begin{array}{l}\text { Swine manure- } \\
\text { rice husk mixed compost }\end{array}$ & 55.0 & 55.0 & 55.0 & 55.0 & 52.4 & 49.7 & 66.8 & 58.9 & 78.5 & 78.5 & \\
\hline & Rape waste & 7.3 & 9.2 & 7.3 & 7.3 & & 6.9 & 7.3 & 7.3 & 7.3 & 7.3 & \\
\hline & Rice straw & 7.7 & 6.2 & 6.5 & 6.8 & 7.1 & 6.3 & 7.0 & 5.7 & & & \\
\hline & Net $P$ input & 70.0 & 70.4 & 68.8 & 69.1 & 59.5 & 63.0 & 81.1 & 72.0 & 85.9 & 85.9 & 72.6 \\
\hline \multirow[t]{5}{*}{ T3 } & Cattle manure compost & 33.2 & 65.5 & 58.9 & 43.6 & 17.9 & & 19.6 & 19.6 & 45.8 & 32.7 & \\
\hline & Rape waste & 9.2 & 9.2 & & & & & & & & & \\
\hline & Rice straw & 3.7 & 3.2 & 2.7 & 7.2 & 4.4 & 6.3 & 7.3 & 4.3 & & & \\
\hline & Chinese milk vetch & & & & & & 2.0 & 2.2 & & & & \\
\hline & Net $\mathrm{P}$ input & 46.1 & 77.9 & 61.6 & 50.8 & 22.3 & 6.3 & 26.9 & 24.0 & 45.8 & 32.7 & 39.4 \\
\hline \multirow[t]{3}{*}{$\mathrm{T} 4$} & Chinese milk vetch & 1.0 & 1.7 & 2.2 & 2.0 & 2.1 & 2.0 & 1.7 & 1.9 & 1.7 & 0.9 & \\
\hline & Rice straw & 8.4 & 6.3 & 6.2 & 7.4 & 7.2 & 6.2 & 7.3 & 6.2 & & & \\
\hline & Net $\mathrm{P}$ input & 8.4 & 6.3 & 6.2 & 7.4 & 7.2 & 6.2 & 7.3 & 6.2 & & & 6.9 \\
\hline \multirow[t]{5}{*}{ T5 } & Basal fertilizer & 15.9 & 55.0 & & & & & & & & & \\
\hline & Top-dressing & 32.3 & 5.2 & & & & & & & & & \\
\hline & Chinese milk vetch & & & ND & ND & 2.2 & 1.9 & 1.9 & 2.6 & 2.0 & 1.4 & \\
\hline & Rice straw & & & 10.2 & 7.5 & 8.3 & 7.5 & 6.7 & 7.1 & & & \\
\hline & Net $P$ input & $\mathrm{X}$ & $\mathrm{X}$ & 10.2 & 7.5 & 8.3 & 7.5 & 6.7 & 7.1 & 0.0 & 0.0 & 5.9 \\
\hline \multirow[t]{4}{*}{ T6 } & Basal fertilizer & 39.3 & & & & & & & & & & \\
\hline & Silica amendments $(0-5-0)$ & & & 34.9 & 34.9 & & & & & & & \\
\hline & Rice straw & & 3.6 & 2.7 & 5.6 & & & & & & & \\
\hline & Net $\mathrm{P}$ input & $\mathrm{X}$ & $\mathrm{X}$ & $\mathrm{X}$ & $\mathrm{X}$ & 0.0 & 0.0 & 0.0 & 0.0 & 0.0 & 0.0 & 0.0 \\
\hline
\end{tabular}

'Net P input' consists of inorganic and organic fertilizer, compost, and returned rice straw, with Chinese milk vetch excluded.

A blank cell indicate 'not applied'. 'ND' is not determinded the amount, but the item applied.

The data in T5 during 1997 - 1998 and in T6 during 1997 - 2000, which are indicated 'X', was excluded in our analysis.

of the additional $\mathrm{P}$ input under P-accumulated soil conditions would support their proposal.

This study aimed to evaluate the input/output balance of $\mathrm{P}$ related to soil $\mathrm{P}$ status in paddy rice fields with various fertilizing practices and hence various $\mathrm{P}$ rates. We also searched for a practical method of managing soil $\mathrm{P}$ status and determine the upper limit of application.

\section{Materials and Methods}

\section{Experimental site}

The experiment was conducted from 1997 to 2006 in paddy fields in Center for Education and Research of Field Science $\left(138^{\circ} 16^{\prime} \mathrm{E}, 34^{\circ} 54^{\prime} \mathrm{N}\right)$, Shizuoka Univ., Fujieda City, central Japan. The annual mean temperature was 16.8 to $17.5^{\circ} \mathrm{C}$ with an average of $16.9^{\circ} \mathrm{C}$, and annual mean precipitation from 1707 to $3399 \mathrm{~mm}$ with the average of $2440 \mathrm{~mm}$ during $1997-2006$. Surface geology is originally swamp. Soil-dressing over $0.8 \mathrm{~m}$ at least had been done in the past, judged from observation of the soil profile. Gley soil (Typic Endoaquept) is formed at present. Topsoil physicochemical properties were as follows: Clayey texture (Silty clay or Light clay), soil pH $5.8-6.7$, Organic C $21-27 \mathrm{~g} \mathrm{~kg}^{-1}$, CEC $27-34 \mathrm{cmol}_{\mathrm{c}} \mathrm{kg}^{-1}$, Base cation saturation index $35-54 \%$, and $\mathrm{P}_{2} \mathrm{O}_{5}$ absorption coefficient $8.6-12.4 \mathrm{~g} \mathrm{~kg}^{-1}$.

\section{Targeted fields and their cropping practices}

Six 10 a-size field plots (T1 to T6) were used (Table 1). They were supplied with various inorganic and organic fertilizers: regionally-recommended commercial fertilizer 
Table 2. Rice grain and straw yield $\left(\mathrm{Mg} \mathrm{ha}^{-1}\right)$ during 1997 to 2006.

\begin{tabular}{ccccccccccccccc}
\hline Field Plot & & 1997 & 1998 & 1999 & 2000 & 2001 & 2002 & 2003 & 2004 & 2005 & 2006 \\
\hline T1 & Grain & 6.65 & 6.51 & 7.05 & 6.68 & 6.49 & 5.82 & 7.28 & 7.82 & 7.31 & 7.21 \\
& Straw & 6.15 & 6.77 & 7.29 & 8.36 & 6.78 & 5.95 & 7.13 & 7.54 & 6.59 & 6.77 \\
T2 & Grain & 5.32 & 5.35 & 5.55 & 4.58 & 5.54 & 6.33 & 5.22 & 6.14 & 6.26 & 6.13 \\
& Straw & 5.65 & 5.92 & 6.16 & 6.48 & 5.76 & 6.13 & 5.20 & 6.80 & 6.16 & 6.15 \\
\multirow{2}{*}{ T3 } & Grain & 5.55 & 4.62 & 5.45 & 5.96 & 6.11 & 6.64 & 4.05 & 3.97 & 5.70 & 5.58 \\
& Straw & 5.88 & 4.86 & 6.53 & 7.96 & 5.74 & 6.24 & 3.95 & 4.99 & 5.78 & 5.94 \\
T4 & Grain & 5.62 & 5.38 & 6.10 & 4.80 & 6.30 & 6.61 & 5.92 & 6.36 & 6.71 & 4.97 \\
& Straw & 5.77 & 5.62 & 6.69 & 6.50 & 5.62 & 6.48 & 5.63 & 6.63 & 5.87 & 4.75 \\
T5 & Grain & 7.74 & 6.80 & 6.16 & 7.22 & 6.59 & 5.98 & 6.30 & 7.30 & 6.27 & 5.38 \\
& Straw & 9.55 & 9.31 & 6.80 & 7.57 & 6.83 & 6.05 & 6.45 & 7.66 & 6.17 & 5.48 \\
T6 & Grain & 6.48 & 5.30 & 4.59 & 5.03 & 5.58 & 4.28 & 4.14 & 4.53 & 4.02 & 4.66 \\
& Straw & 6.56 & 4.84 & 5.09 & 5.80 & 6.24 & 4.36 & 4.35 & 4.98 & 3.87 & 4.94 \\
\hline
\end{tabular}

Rice cultivar was Oryza sative L. cv Hitomebore, with a exception in T5 plot, where cv Aichinokaori planted during 1997 - 1998.

(T1), swine manure-rice husk mixed compost and rape waste (T2), cattle manure compost (T3), Chinese milk vetch (Astragalus sinicus L.) as green manure (T4, T5), and not fertilized (T6 plot). The rates of compost applied in T2 and $\mathrm{T} 3$ plots were lower than $10 \mathrm{Mg} \mathrm{ha}^{-1} \mathrm{yr}^{-1}$, which has been recommended for maintaining soil organic matter and hence improving soil conditions in Japan. However, first $2 \mathrm{yr}(1997-1998)$ in the T5 plot and first $4 \mathrm{yr}$ (1997 - 2000) in the T6 plot were excluded in following analysis, because they were supplied with commercial inorganic fertilizers: the T5 plot was referred to as 'green manuring', but was supplied with the commercial fertilizers like the T1 plot in the first 2 yr (1997-1998); the T6 plot was referred to as 'not fertilized', but the T6 plot received some P-containing fertilizers and/or amendments in the first 4 yr $(1997-2000)$.

Rice cultivar was Oryza sative L. cv Hitomebore. T1, T5 and $\mathrm{T} 6$ plots received fungicide and bactericide, two or three times a year, insecticide, once or twice a year and herbicide treatment, once a year. In all plots, ca. 2-week-old seedlings were planted in early June. Midseason drainage was carried out during about 2 weeks in mid-July. Rice plants were harvested in late September.

\section{Estimate of partial phosphorus balance (PPB)}

PPB was estimated by subtracting the amount of $\mathrm{P}$ taken up by rice crop from the amount of $\mathrm{P}$ applied as commercial fertilizer, composts and rice straw. Chinese milk vetch, however, took up indigenous $\mathrm{P}$ in the soil and then returned all of the $\mathrm{P}$ to the soil. Therefore, the $\mathrm{P}$ input and output via Chinese milk vetch were excluded from the estimates.

Phosphorus input is shown in Table 1. Phosphorus input from composts and rape waste was estimated by multiplying the application rate of individual items by their $\mathrm{P}$ contents assumed as follows: swine manure-rice husk mixed compost, 3.0\% (Yamaguchi et al., 2000); cattle manure compost, 1.0\% (Yamaguchi et al., 2000); rape seed waste, $2.1 \%$ as $\mathrm{P}_{2} \mathrm{O}_{5}$ (Date, 1988). Rice straw was assumed to have $0.11 \% \mathrm{P}$ (see description below). On the other hand, air-dried matter yield of grain and straw was investigated for 50 hills (5 replicates of 10 hills) from each plot at harvest (Table 2). Additional samples were collected from 2003 to 2006 (3 replicates of 6 hills for 2003 - 2004, and 5 replicates of 6 hills for 2005 - 2006), and then were analyzed for $\mathrm{P}$ content in the rice grain and straw. The $\mathrm{P}$ content was determined by using conc. nitric acid + perchloric acid digestion and then molybdate-blue colorimetry. The phosphorus content of grain showed a mean value of $0.24 \%$ with a CV $9 \%$ and a median value of $0.24 \%$ across plots and years, indicating the value distributed normally and within a narrow range. Similarly, straw $\mathrm{P}$ content had a mean value of $0.11 \%$ with a $\mathrm{CV}$ of $16 \%$ and a median value of $0.10 \%$ (data not shown). These values were consistent with that reported in Ono et al. (1999). In addition, the grain and straw $\mathrm{P}$ content was not significantly different among plots $(p=0.35-0.75)$ by means of two-way analysis of variance (plot $\times$ year), in spite of the different $P$ source and quantity among plots. Significant yearly variation in straw P content, however, was observed. The P contents were available only for the last 4 years, but not the first 6 years, because of the lack of samples for analyzing $\mathrm{P}$ contents. We assumed that $\mathrm{P}$ content of grain and straw were 0.24 and $0.11 \%$, respectively, and adopted these values in all cases. Phosphorus uptake was estimated by multiplying the air-dried matter of grain and straw by their 

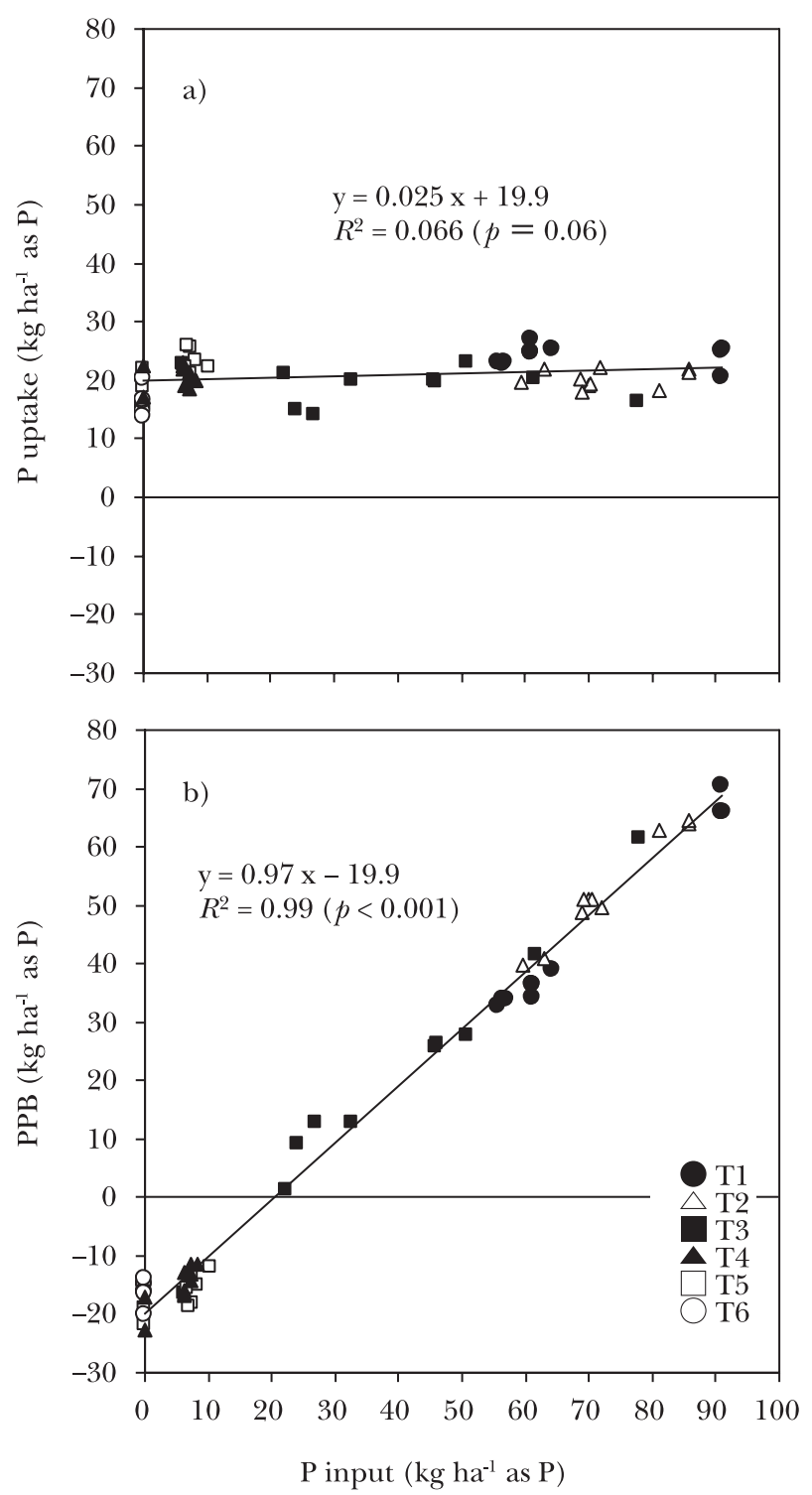

Fig. 1. Correlation of estimated $\mathrm{P}$ input with (a) estimated $\mathrm{P}$ uptake and (b) partial P balance (PPB) in $\mathrm{kg} \mathrm{ha}^{-1} \mathrm{yr}^{-1}$. The data during the first 6 years (1997 to 98) is omitted in T5 plot, and the data during first 4 years (1997 to 2000) is omitted in T6 plot.

$\mathrm{P}$ content, and the values were converted to $\mathrm{kg} \mathrm{ha}^{-1}$ as $\mathrm{P}$.

\section{Measurement of the soil phosphorus status}

Soil samples were obtained from surface horizons $(0-15 \mathrm{~cm})$ of the 6 plots, irregularly during the 10 years. Soil sample collected at 5 to 20 points per plot (differed with the year), air-dried, and then sieved through $2 \mathrm{~mm}$ to make a bulk sample. Soil total $\mathrm{P}$ content was measured by ignition-extraction (Egawa and Nonaka, 1980). The available $\mathrm{P}$ test was conducted according to Bray- and Truog-P method (Nanzyo, 1997). The soil P was measured with at least two replicates. The result was expressed in $\mathrm{mg}$ $\mathrm{kg}^{-1}$ as $\mathrm{P}$ on a dry soil basis.

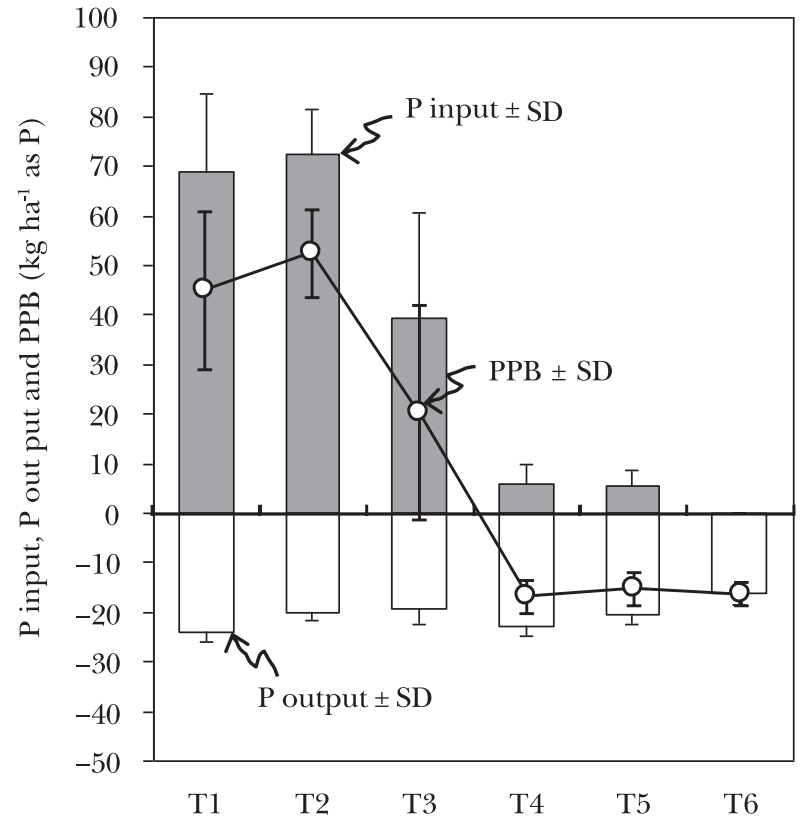

Fig. 2. The estimated annual $\mathrm{P}$ input, $\mathrm{P}$ output, and PPB. Grayish and blank bar indicate $\mathrm{P}$ input and output, respectively. Open circles tied together with a line indicate PPB. Vertical bars are SD. However, the data during the first 6 years (1997 to 98) is omitted in T5 plot, and the data during the first 4 years (1997 to 2000) is omitted in T6 plot.

\section{Statistical analysis}

The data for the entire 10 years in T1, T2, T3 and T4 plots, last 6 years in T5 plot, and last 8 years in T6 plot were subjected to the analyses. The correlations between $\mathrm{P}$ input and $\mathrm{PPB}$ as well as $\mathrm{P}$ output (rice $\mathrm{P}$ uptake) were investigated using simple regression analysis. On the other hand, the increasing or decreasing trend of soil total $\mathrm{P}$ as well as Bray- and Truog-P content was estimated by means of least square procedure. Since the P input (Table 1) and hence the PPB varied with the year, the cumulative PPB was related to the change in the soil total $\mathrm{P}$ content using simple regression analysis. Also, the correlations of the soil total P with Bray- and Truog-P were investigated by simple regression analysis. Statistical analyses were done by Analytical tools of Excel 2003 (Microsoft Corp.).

\section{Results}

A statistically significant correlation was not observed between $\mathrm{P}$ input and rice $\mathrm{P}$ uptake $(p=0.06)$ (Fig. 1a). The regression coefficient was not significantly different from zero. The $\mathrm{P}$ uptake seemed not to respond to the $\mathrm{P}$ input. As a result, a strong positive correlation was observed between the P input and PPB $(p<0.001)$ (Fig. 1b). Phosphorus input of $20.5 \mathrm{~kg} \mathrm{ha}^{-1}$ was evenly balanced with the $\mathrm{P}$ output, i.e. $\mathrm{PPB}=0$.

Fig. 2 shows the mean values for $\mathrm{P}$ balance. The estimated annual mean $\mathrm{P}$ input varied with the plot. T1 plot had the high $\mathrm{P}$ input of $69 \mathrm{~kg} \mathrm{ha}^{-1} \mathrm{yr}^{-1}$, derived mainly 

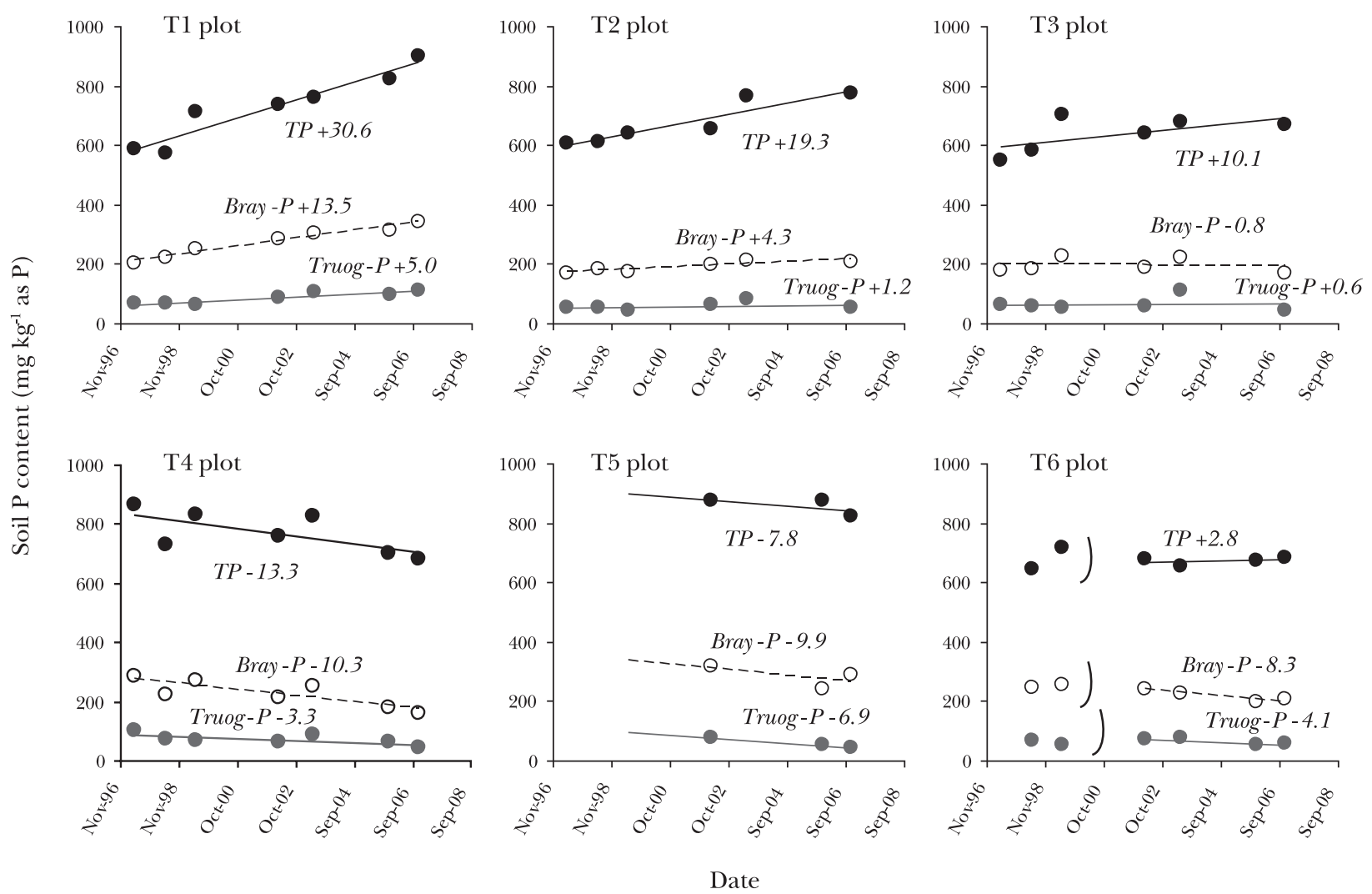

Fig. 3. Changes in total and available $\mathrm{P}$ content of soil. The italics show the annual change of soil $\mathrm{P}$ in $\mathrm{mg} \mathrm{kg}^{-1} \mathrm{yr}^{-1}$, derived from the regression line obtained by the means slope by means of least square procedure against date (year). However, the data during first 6 years (1997 to 1998) is omitted for T5 plot, and the data during first 4 years (1997 to 2000) is omitted in T6 plot.

from commercial fertilizer as well as P-containing silica amendment (42 and $24 \mathrm{~kg} \mathrm{ha}^{-1} \mathrm{yr}^{-1}$ on the average, respectively). T2 and T3 plots had also a high $\mathrm{P}$ input of 73 and $39 \mathrm{~kg} \mathrm{ha}^{-1} \mathrm{yr}^{-1}$, respectively, due to the animal waste composts. In contrast, only a part of rice straw $\mathrm{P}$ were returned (P input) to T4 and T5 plots $\left(5.5\right.$ and $5.9 \mathrm{~kg} \mathrm{ha}^{-1}$ $\mathrm{yr}^{-1}$, respectively), and $\mathrm{T} 6$ plot received none of P. On the other hand, rice $\mathrm{P}$ uptake was estimated to be $20.5 \mathrm{~kg} \mathrm{ha}^{-1}$ $\mathrm{yr}^{-1}$ on the average in all plots. Rice $\mathrm{P}$ uptake, however, varied with the plot, ranging from 16 (T6) to $24 \mathrm{~kg} \mathrm{ha}^{-1} \mathrm{yr}^{-1}$ (T1). The estimated annual mean PPB was mostly positive in the $\mathrm{T} 1 \mathrm{plot}\left(+45 \mathrm{~kg} \mathrm{ha}^{-1} \mathrm{yr}^{-1}\right)$ as well as in the T2 $(+52 \mathrm{~kg}$ $\left.\mathrm{ha}^{-1} \mathrm{yr}^{-1}\right)$ and T3 plot $\left(+20 \mathrm{~kg} \mathrm{ha}^{-1} \mathrm{yr}^{-1}\right)$. These 3 plots received the excess $\mathrm{P}$ over the crop requirement. In contrast, the PPB in T4, T5 and T6 plots were negative (-17 to $-15 \mathrm{~kg} \mathrm{ha}^{-1} \mathrm{yr}^{-1}$ ).

Soil total $\mathrm{P}$ content across plots and years ranged from 550 to $900 \mathrm{mg} \mathrm{kg}^{-1}$ (Fig. 3). The PPB varied with the year in all plots. Nevertheless, soil total P content showed an increasing trend in T1, T2 and T3 plots with the positive $\mathrm{PPB}$, whereas decreasing trend in $\mathrm{T} 4$ and $\mathrm{T} 5$ plots with the negative PPB, except for the T6 plot (Fig. 3). The change in soil total $\mathrm{P}$ content was closely related to the cumulative PPB. Positive trend of cumulative PPB in T1, T2 and T3 plots caused a linear increase in the soil total P content,

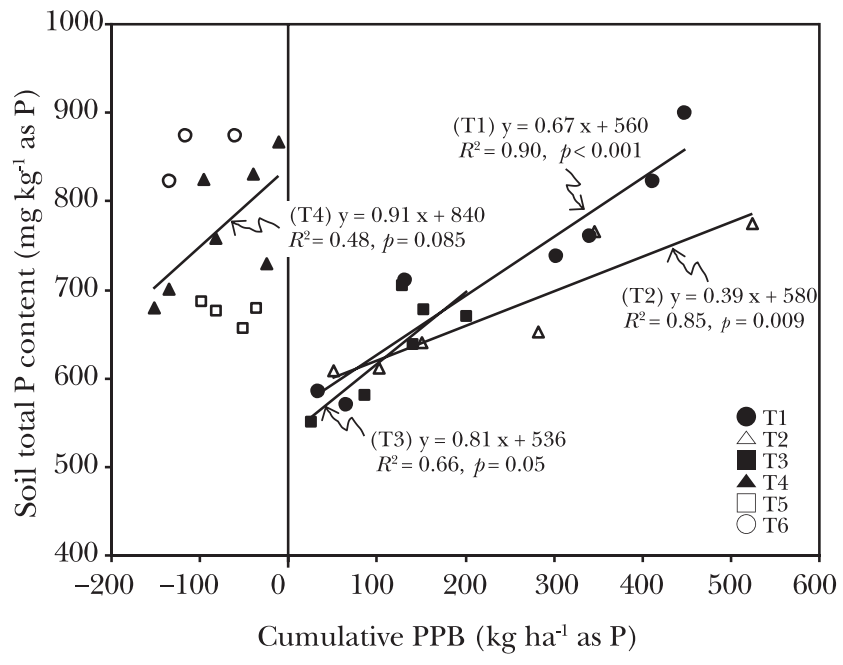

Fig. 4. Linear relationships between cumulative PPB and soil total $\mathrm{P}$ content.

while a negative trend of cumulative PPB in T4 plot caused a linear decrease (Fig. 4). The total $\mathrm{P}$ content of surface $(0-15 \mathrm{~cm})$ soil was expected to increase by $67 \mathrm{mg} \mathrm{kg}^{-1}$ in T1 plot, when cumulative PPB became $+100 \mathrm{~kg} \mathrm{ha}^{-1}$. Assuming that a soil bulk density is $1 \mathrm{Mg} \mathrm{m}^{-3}$, we estimated the increase of soil total P in the T1 surface soil to be +101 
$\mathrm{kg} \mathrm{ha}^{-1}$. Similarly, cumulative PPB of $+100 \mathrm{~kg} \mathrm{ha}^{-1}$ for T2, $\mathrm{T} 3$ and T4 plots led the surface soil to increase the soil total $\mathrm{P}$ by +59 to $+137 \mathrm{~kg} \mathrm{ha}^{-1}$, which nearly resembled the T1 plot, even if the rate was scattered a little because of uncertainty of PPB estimate and fluctuation of soil analysis. However, unclear relations between cumulative PPB and soil total $\mathrm{P}$ content were observed in T5 and T6 plots, probably due to the shortage of the data.

Similarly, Bray- and Truog-P ranged from 120 to 260, and from 44 to $110 \mathrm{mg} \mathrm{kg}^{-1}$, respectively, across plots and years (Fig. 3). According to the PPB, soil Truog- and Bray-P content also showed an increasing trend in the $\mathrm{T} 1, \mathrm{~T} 2$ and $\mathrm{T} 3$ plots, whereas a decreasing trend in the T4, T5 and T6 plots, except for Bray-P in T3 plot (Fig. 3). Soil Bray-P as well as Truog-P content was significantly correlated with the soil total P content (Fig. 5). However, the regression coefficient was 0.38 and 0.09 for Bray- and Truog-P content, respectively: the increasing or decreasing rates of Bray- and Truog-P content was lower than those of soil total P content.

\section{Discussion}

The $\mathrm{P}$ input varied among plots from 0 to $73 \mathrm{~kg} \mathrm{ha}^{-1} \mathrm{yr}^{-1}$. However, the rice $\mathrm{P}$ uptake was approximately $20 \mathrm{~kg} \mathrm{ha}^{-1}$, and did not respond to the $\mathrm{P}$ input. The results were attributed to a large amount of plant-available $\mathrm{P}$ in our field soils. The Truog-P contents across plots and years were higher than a common diagnostic standard of $44 \mathrm{mg}$ $\mathrm{kg}^{-1}$ as P without exception. Kawamoto (1984) demonstrated that the Bray-P content was higher than $109 \mathrm{mg} \mathrm{kg}^{-1}$ as $\mathrm{P}$ at the maximum tillering stage, which enables normal tiller development in the warm-temperate region of Japan. The content higher than $26 \mathrm{mg} \mathrm{kg}^{-1}$ was also demonstrated not to decrease the rice yield (Kawamoto, 1984). The Bray-P content of our soils satisfied obviously the critical levels proposed by Kawamoto (1984). However, the P uptake rate was higher in $\mathrm{T} 1$ plot and lower in $\mathrm{T} 6$ plot than that in the other plots. Nitrogen, besides $\mathrm{P}$, is the most important nutrient for crop. In the $\mathrm{T} 1$ plot, fertilizer nitrogen was applied at the recommended rate. A part of nitrogen symbiotically-fixed by leguminous green manure (T4 and T5 plots) and compost-derived nitrogen (T2 and T3 plots) could be available for rice crop. On the other hand, the T6 plot received no anthropogenic nitrogen. Nagumo et al. (2009) observed a significant correlation between the amount of nitrogen uptake and the rice yield in our 6 plots: the order of nitrogen uptake rate was $\mathrm{T} 1>\mathrm{T} 4$, $\mathrm{T} 5$ $>\mathrm{T} 2, \mathrm{~T} 3>\mathrm{T} 6$ plot, and it agreed with the order of the rice yield. Increasing rice yield derived from higher nitrogen input enhanced $\mathrm{P}$ uptake through better crop growth (Singh et al., 2007). Dorbermann et al. (1996) also indicated that the rice $\mathrm{P}$ uptake could vary according to the rice yield, which was largely influenced by nitrogen availability. It is indicated that the rice $\mathrm{P}$ uptake could be

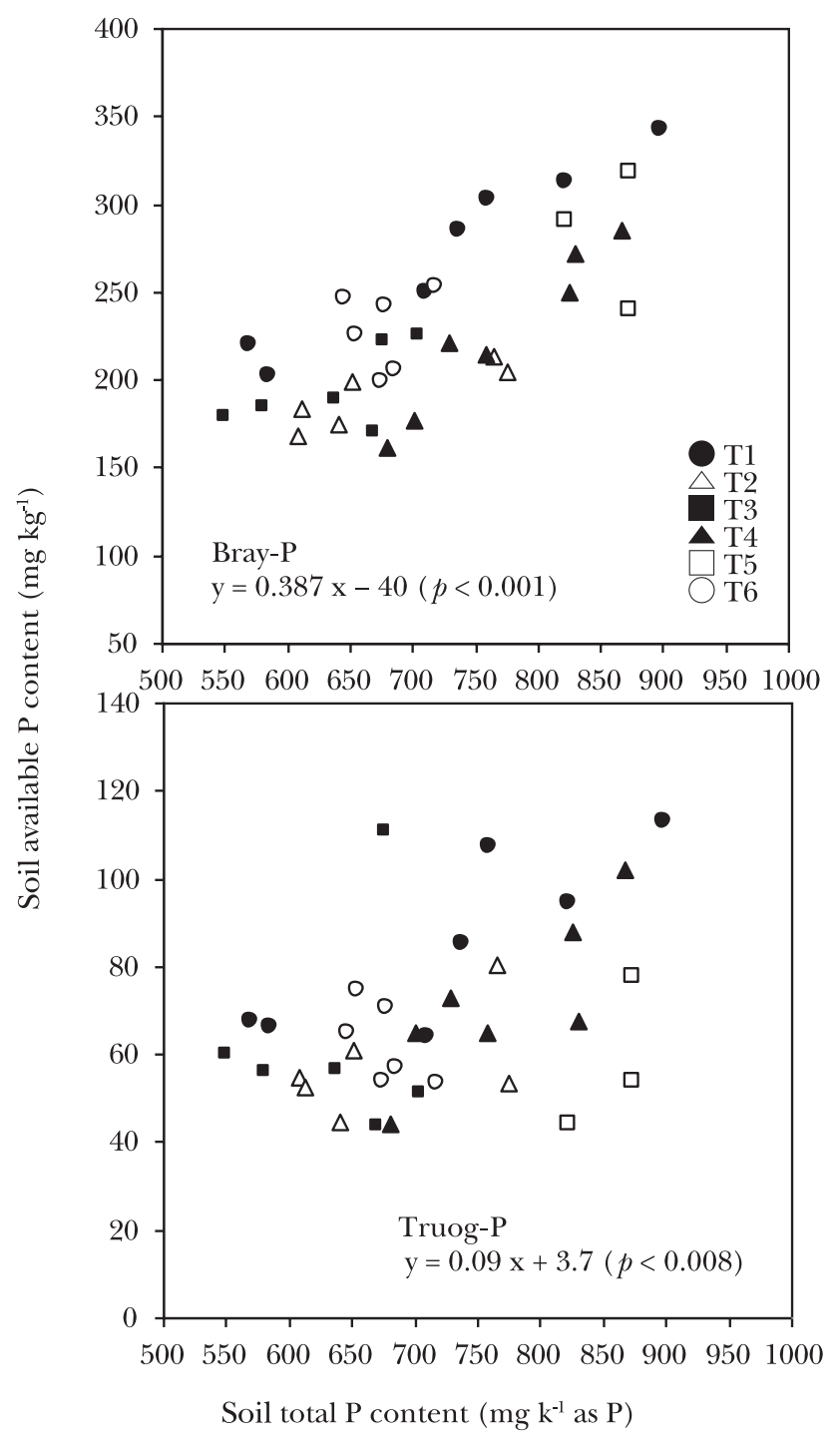

Fig. 5. Relationship between the total $\mathrm{P}$ and available $\mathrm{P}$ contents of soils. The data from 1997 to 2006 are used in T1 to T4 plots, but the data from 1999 to 2006 and from 2001 to 2006 in T5 and T6 plot, respectively.

determined by the nitrogen availability in our fields. In other words, our P accumulated soil had the ability to provide the $\mathrm{P}$ enough to satisfy the rice requirement according to the nitrogen availability. It is obvious that $\mathrm{P}$ was not a limiting factor in the rice yield in our P-rich soils. In our fields, where the rice $\mathrm{P}$ uptake did not respond to any $\mathrm{P}$ input, paddy rice could be cultivated without any P-containing fertilizers and amendments.

As a result, increase in the $\mathrm{P}$ input led to the linear increase in PPB. The positive correlations between PPB and soil total $\mathrm{P}$ content have been reported in long-term paddy and upland field trials (Oehl et al., 2002; Blake et al., 2003; Lee et al., 2004; Han et al., 2005). In this study, the change in soil total $\mathrm{P}$ content was related to the cumulative $\mathrm{PPB}$, because the $\mathrm{P}$ input varied greatly with the year. The cumulative increase in PPB caused an 
increase in the soil total $\mathrm{P}$ content, while the cumulative decrease in PPB caused the decrease in the soil total P content. These findings confirm that most of the residual $\mathrm{P}$ was accumulated within the soil profile, particular in the surface horizon. In addition, more important confirmation is that PPB is able to use for predicting the changes in the soil TP content. PPB has also been reported to predict available soil $\mathrm{P}$ test value in some studies (Dorbermann et al., 1996; Singh et al., 2000; Nishio, 2003; Han et al., 2005).

Control of the $\mathrm{P}$ input is important to avoid additional $\mathrm{P}$ accumulation (Sharpley et al., 2001; Hart et al., 2004). P input evenly balanced with the $\mathrm{P}$ output was estimated to be ca. $20 \mathrm{~kg} \mathrm{ha}^{-1} \mathrm{yr}^{-1}$. This corresponded to the averaged $\mathrm{P}$ uptake. This rate is supported by a pioneer study conducted by Ono et al. (1999). They assumed that only grain is removed, and recommended a $\mathrm{P}$ rate of $17 \mathrm{~kg} \mathrm{ha}^{-1}$ $\mathrm{yr}^{-1}\left(40 \mathrm{~kg} \mathrm{ha}^{-1} \mathrm{yr}^{-1}\right.$ as $\mathrm{P}_{2} \mathrm{O}_{5}$ ) based on a balanced $\mathrm{P}$ input with the common $\mathrm{P}$ harvesting rate under $\mathrm{P}$ accumulated soil conditions. Dorbermann et al. (1996) also recommended the ample $\mathrm{P}$ input of $20-25 \mathrm{~kg} \mathrm{ha}^{-1}$ as $\mathrm{P}$ to maintain rice yields of $5-6 \mathrm{Mg} \mathrm{ha}^{-1}$ based on the data from 11 long-term experiments in Asian countries. The higher $\mathrm{P}$ input in the T1 plot was attributed to the application of commercial fertilizer $\mathrm{P}$ exceeding the rice $\mathrm{P}$ uptake. The $\mathrm{T} 1$ plot was further supplemented with the P-containing soil amendment. The positive PPB in the T2 and T3 plots, where received animal waste composts at commonly recommended rate of $10 \mathrm{Mg} \mathrm{ha}^{-1}$ for improving soil conditions, also indicated not to be able to neglect the $\mathrm{P}$ derived from P-containing soil amendments like composts in the $\mathrm{P}$ accounting. Under the excess $\mathrm{P}$ accumulated soil conditions like our fields, $\mathrm{P}$ fertilization should be restricted to the rate of $20 \mathrm{~kg} \mathrm{ha}^{-1} \mathrm{yr}^{-1}$ (corresponding to 46 $\mathrm{kg} \mathrm{ha}^{-1} \mathrm{yr}^{-1}$ as $\mathrm{P}_{2} \mathrm{O}_{5}$ ). It must include all of inorganic and organic fertilizers and amendments, as a matter of course.

In contrast to these recommendations, the averaged $\mathrm{P}$ rate of current commercial fertilizer $\mathrm{P}$ consumption in paddy rice fields was $40-47 \mathrm{~kg} \mathrm{ha}^{-1} \mathrm{yr}^{-1}$ as $\mathrm{P}$ in Japan. Additional $\mathrm{P}$ was supplemented using compost and other soil amendments (Nishio, 2002, 2003; Mishima et al., 2003). Lee et al. (2004) and Park et al. (2004) demonstrated that $\mathrm{P}$ fertilization at the rate of 45 to $56 \mathrm{~kg} \mathrm{ha}^{-1} \mathrm{yr}^{-1}$, comparable to our $\mathrm{T} 1$ plots and the nation-wide average, led to the increase in total P content in paddy soil. Indeed, $\mathrm{P}$ accumulation has been increasing throughout Japan (Goto et al., 2003; Obara and Nakai, 2004).

Only a small amount of $\mathrm{P}$ in runoff water and leachate is negligible agronomically, but it could be often enough to make the water bodies eutrophic environmentally (Hart et al., 2004). Increased quantity of the labile $P$ would enhance the $\mathrm{P}$ in the soil solution. Enhanced soil solution $\mathrm{P}$ is readily available for crop plants (Hedley, 2008). Hart et al. (2004), on the other hand, emphasized that P loss potentially enhance, as a general rule, once soil test $\mathrm{P}$ values exceed the crop requirement. In UK upland field, increase in Olsen-P value more than $60 \mathrm{mg} \mathrm{kg}^{-1}$ could enhance the $\mathrm{P}$ concentration in runoff water linearly (Heckrath et al., 1995). Allen et al. (2006) investigated the relationship between soil $\mathrm{P}$ test value and the simulated runoff $\mathrm{P}$ in US Midwest non-calcareous upland soils. They indicated that Bray-P more than $410 \mathrm{mg} \mathrm{kg}^{-1}$ may have a risk of $\mathrm{P}$ concentration over $1 \mathrm{mg} \mathrm{L}^{-1}$ in the runoff water. Our study fields had soil $\mathrm{P}$ test value of 44 to $110 \mathrm{mg} \mathrm{kg}^{-1}$ as Truog-P and 160 to $340 \mathrm{mg} \mathrm{kg}^{-1}$ as Bray-P in current (Fig. 3). Increased available $P$ content in paddy soil may cause an enhanced $\mathrm{P}$ runoff to the surface waters (Sharpley et al., 2001; Wang et al., 2001; Zhang et al., 2003). We needed to investigate $\mathrm{P}$ runoff with special reference to the soil $\mathrm{P}$ status in paddy fields. Besides the restriction of the $\mathrm{P}$ input, it would motive to settle the upper limit against the soil $\mathrm{P}$ test in the near future. Moreover, the increasing or decreasing rates of such Bray- and Truog-P content was lower than those of soil total P content, as indicated in this study. It is implied that prompt decrease in Bray- and Truog-P contents might be difficult to achieve, even if the soil total $\mathrm{P}$ content was decreased by the restricted $\mathrm{P}$ input (i.e. zero or negative PPB). To achieve the desirable level of soil test $\mathrm{P}$, further restriction of $\mathrm{P}$ input, to less than the $20 \mathrm{~kg} \mathrm{ha}^{-1} \mathrm{yr}^{-1}$, might be needed under excess $\mathrm{P}$ accumulated conditions. This severe restriction would be reasonable, if we consider that the rice growth and yield does not respond to the additional $\mathrm{P}$ input, as shown in the present study.

\section{Acknowledgements}

We thank Assistant Professor T. Asai for providing yield data and a part of soil samples. We also acknowledged Mr. K. Nishikawa and other technical stuffs of the Center for Education and Research of Field Science, Shizuoka University, for their assistance of practical operation in field management.

\section{References}

Allen, B.L., Mallarino, A.P., Klatt, J.G., Baker, J.L., and Camara, M. 2006. Soil and surface runoff phosphorus relationships for five typical USA Midwest soils. J. Environ. Qual. 35: 599-610.

Blake, L., Johnston, A.E., Poulton, P.R. and Goulding, K.W.T. 2003. Changes in soil phosphorus fractions following positive and negative phosphorus balances for long periods. Plant Soil 254: 245261.

Cho, J.Y., Han, K.W. and Choi, J.K. 2000. Balance of nitrogen and phosphorus in a paddy field of central Korea. Soil Sci. Plant Nutr. 46: 343-354.

Date, N. 1988. Organic Fertilizers and Microbiological Amendments (Yu-kishitu Hiryo to Biseibutu Shizai). Rural Culture Association (Nousan Gyoson Bunka Kyoukai), Tokyo. 1-212*.

Dorbermann, A., Cassman, K.G., Sta. Cruz, P.C., Adviento, M.A.A. and Pampolino, M.F. 1996. Fertilizer inputs, nutrient balance and soil nutrient supplying power in intensive, irrigated rice systems. III. Phosphorus. Nutr. Cycle. Agroecosyst. 46: 111-125. 
Egawa, T. and Nonaka, M. 1980. Studies on soil organic phosphorus 1. Organic phosphorus content in some Andosols. Bull. .Fac. Agric. Meiji Univ. 52: 55-68**.

Goto, E., Miura, S., Nomura, M. and Inatsu, O. 2003. The present condition of chemical properties of paddy soils in Hokkaido. Jpn. J. Soil Sci. Plant Nutr. 74: 475-483**.

Han, X.Z., Song, C.Y., Wang, S.Y. and Tang, C. 2005. Impact of longterm fertilization on phosphorus status in Black soil. Pedosphere 15: 319-326.

Hart, M.R., Quin, B.F. and Nguyen, M.L. 2004. Phosphorus runoff from agricultural land and direct fertilizer effects: A review. J. Environ. Qual. 33: 1954-1972.

Heckrath, G., Brookes, P.C., Poulton, P.R. and Goulding, K.W.T. 1995. Phosphorus leaching from soils containing different phosphorus concentrations in the Broadbalk experiment. $J$. Environ. Qual. 24: 904-910.

Hedley, M.J. 2008. Techniques for assessing nutrient bioavailability in soils: Current and future issues. In Naidu R. ed., Chemical Bioavailability in Terrestrial Environments. Elsevier, Amsterdam, 283-327.

Kawamoto, Y. 1984. Phosphate availability and effect in warmtemperate paddy rice soils. In Japanese Society of Soil Science and Plant Nutrition ed., Paddy Rice Soil and Phosphate-supplying Capacity and Fertilization. Hakuyu-sha, Tokyo. 87-126*.

Kim, J.S., Oh, S.Y. and Oh, K.Y. 2006. Nutrient runoff from a Korean rice paddy watershed during multiple storm events in the growing season. J. Hydrol. 327: 128-139.

Lee, C.H., Park, C.Y., Park, K.D., Jeon, W.T. and Kim, P.J. 2004. Longterm effects of fertilization on the forms and availability of soil phosphorus in rice paddy. Chemosphere 56: 299-304.

Mishima, S., Itahashi, S., Kimura, R. and Inoue, T. 2003. Trends of phosphate fertilizer demand and phosphate balance in farmland soils in Japan. Soil Sci. Plant Nutr. 49: 39-45.

Nagumo, T., Kubota, K., Ooi, Y., Kanazawa, H. and Nishikawa, K. 2009. Paddy rice productivity and $\mathrm{N}$ use efficiency on a Gley soil under green manuring and/or compost application. Jpn. J. Crop Sci. 78(Extra issue 2): 190-191*.

Nanzyo, M. 1996. Progress and prospect of the research on paddy soil management under various rice growing system. 1. Progress in nutrient behavior and management research on paddy soil (2) Phosphorus. Jpn. J. Soil Sci. Plant Nutr. 67: 317-321*.

Nanzyo, M. 1997. Available phosphate. In Editorial Committee for Methods of Soil Environment Analysis (Dojyo-Kankyo-Bunsekihou Henshu-Iinkai) ed., Methods of Soil Environment Analysis (DojyoKankyo-Bunsekihou), Hakuyu-sha, Tokyo. 267-273*.

Nishio, M. 2002. Recent trends of chemical fertilizer consumption in Japan. Jpn. J. Soil Sci. Plant Nutr. 73: 219-225*.

Nishio, M. 2003. Analysis of the actual status of phosphate application in arable farming in Japan. Jpn. J. Soil Sci. Plant Nutr.
74: $435-443^{* *}$.

Obara, H. and Nakai, M. 2004. Available phosphate of arable lands in Japan. Changes of soil Characteristics in Japanese arable lands (II). Jpn. J. Soil Sci. Plant Nutr. 75: 59-67**.

Oehl, F., Oberson, A., Tagmann, H.U., Besson, J.M., Dubois, D., Mäder, P., Roth, H.R. and Frossard, E. 2002. Phosphorus budget and phosphorus availability in soils under organic and conventional farming. Nutr. Cycle. Agroecosyst. 62: 25-35.

Ono, S., Ogawa, Y., Takahashi, S. and Ohno, S. 1999. The removal of phosphorus and potassium by rice from paddy fields and appropriate applying amount of these elements to rice. Jpn. J. Soil Sci. Plant Nutr. 70: 320-323*.

Ooya, M., Yamamoto, S. and Kuyama, H. 2007. Effect of successive application of compost to no tillage-paddy field on inorganic phosphorus leaching during winter cropping. Jpn. J. Soil Sci. Plant Nutr. 78: 237-243**.

Park, M., Singvilay, O., Shin, W., Kim, E., Chung, J. and Sa, T. 2004. Effects of long-term compost and fertilizer application on soil phosphorus status under paddy cropping system. Commun. Soil Sci. Plant Anal. 35: 1635-1644.

Pheav, S., Bell, R.W., Kirk, G.J.D. and White, P.F. 2005. Phosphorus cycling in rainfed lowland rice ecosystems on sandy soils. Plant Soil 269: 89-98.

Shan, Y.H., Yang, L.Z., Yan, T.M. and Wang, J.G. 2005. Downward movement of phosphorus in paddy soil installed in large-scale monolith lysimeters. Agric. Ecosyst. Environ. 111: 270-278.

Sharpley, A.N., McDowell, R.W. and Kleinman, P.J.A. 2001. Phosphorus loss from land to water: integrating agricultural and environmental management. Plant Soil 237: 287-307.

Singh, Y., Dobermann, A., Singh, B., Bronson, K.F. and Khind, C.S. 2000. Optimal phosphorus management strategies for wheat-rice cropping on a Loamy Sand. Soil Sci. Soc. Am. J. 64: 1413-1422.

Singh, M., Reddy, K.S., Singh, V.P. and Rupa, T.R. 2007. Phosphorus availability to rice (Oryza sativa L.)-wheat (Triticum estivum L.) in a Vertisoil after eight years of inorganic and organic fertilizer additions. Bioresour. Technol. 98: 1474-1481.

Yamaguchi, T., Harada, Y. and Tsuiki, M. 2000. Basic data of animal waste composts. Misc. Natl. Agric. Res. Cent. 41: 1-178*.

Wang, K., Zhang, Z., Zhu, Y., Wang, G., Shi, D. and Christie, P. 2001. Surface water phosphorus dynamics in rice fields receiving fertilizer and manure phosphorus. Chemosphere 42: 209-214.

Zhang, H.C., Cao, Z.H., Shen, Q.R. and Wong, M.H. 2003. Effect of phosphate fertilizer application on phosphorus (P) losses from paddy soils in Taihu Lake Region I. Effect of phosphate fertilizer rate on P losses from paddy soil. Chemosphere 50: 695-701.

\footnotetext{
* In Japanese.

** In Japanese with English summary.
} 